\title{
Cross-slope variations of organic carbon and bacteria in the Gulf of Lions in relation to water dynamics (northwestern Mediterranean)
}

\author{
Séri C. Yoro ${ }^{1}$, Richard Sempéré ${ }^{1, *}$, Carol Turley ${ }^{2}$, Maria A. Unanue ${ }^{3}$, \\ Xavier Durrieu de Madron ${ }^{4}$, Micheline Bianchi ${ }^{1}$ \\ ${ }^{1}$ Laboratoire de Microbiologie Marine, CNRS/INSU UPR 223, Case 907, Université de la Méditerranée, Campus de Luminy. \\ F-13288 Marseille Cedex 9, France \\ ${ }^{2}$ Plymouth Marine Laboratory, Citadel Hill, Plymouth PL1 2PB, United Kingdom \\ ${ }^{3}$ Departamento Inmunologia, Microbiologia y Parasitologia, Facultad de Ciencias Universidad del Pais Vasco, Apdo. 644, \\ E-48080 Bilbao, Spain \\ ${ }^{4}$ Laboratoire de Sédimentologie el Géochimie Marines, CNRS/INSU UA 715, Université de Perpignan, \\ F-66860 Perpignan Cedex, France
}

\begin{abstract}
During November 1994, seawater samples were collected in the Gulf of Lions in the northwestern Mediterranean Sea. Four stations were chosen to cover a range of environments, from coastal seawater near Marseille, France, to open ocean waters 30 miles off the coast. Samples were studied for dissolved and particulate organic carbon (DOC and POC) as well as bacterial abundance and chlorophyll $a$ (chl a). In the water column, DOC comprized 93 to $99 \%$ of total organic carbon, ranged from 65 to $118 \mu \mathrm{M}$ and was lower in deep waters on the slope. Considering an average $82 \mu \mathrm{M}$ DOC concentration measured in the surface layer $(0$ to $70 \mathrm{~m})$ of the slope as typical of the core of the northwestern Mediterranean current, we estimated the DOC load carried by the current to range from 82 to $164 \times$ $10^{3} \mathrm{~mol} \mathrm{C} \mathrm{s}{ }^{-1}$, which was ca 100 times higher than the Rhone River input for the same period. Chl a concentrations were up to $224 \mathrm{ng} \mathrm{l}^{-1}$ whereas bacterial concentrations ranged from 0.9 to $7.7 \times 10^{5} \mathrm{cells} \mathrm{ml}^{-1}$ making up 17 to $24 \%$ of the POC in the surface layer $(0$ to $70 \mathrm{~m})$. Bacterial-C/phytoplankton-C ratios around the slope were higher than offshore and were in good agreement with bacterial production/ primary production ratios. These results indicate a time lag between autotrophic phytoplanktonic and heterotrophuc bacterial activities and/or differences in the food web structure from the slope to the seaward end of the section. Although the bacterial-C/phytoplankton- $C$ ratios were lower at the coastal station, the lowest primary production as well as higher bacterial production/primary production ratios were calculated in this area. This suggests that a part of bacterial production was sustained by terrestrial organic matter on the shelf Variations among stations sampled during comparable climatological conditions revealed the existence of a spatial gradient across the slope
\end{abstract}

KEY WORDS: Dissolved organic carbon Particulate organic carbon Bacteria Chlorophyll a Northwestern Mediterranean Sea

\section{INTRODUCTION}

Dissolved organic carbon (DOC) represents the largest pool of organic matter in seawater and thus it is important to understand how rapidly and efficiently it is turned over by bacteria (Coffin et al. 1993). In coastal

\footnotetext{
- Addressee for correspondence.

E-mail: sempere@luminy.univ-mrs.fr

environments, in addition to autochthonous biogenic sources (Wangersky 1978, Romankevich 1984, Jumars et al. 1989), large quantities of DOC are exported from the land to the continental margins through the rivers and the nepheloid layers (Richey et al. 1980, Mantoura \& Woodward 1983, Cauwet et al. 1990, Sempéré et al. 1994, Repeta et al. 1995) with varying nutritional value for bacteria (Moran \& Hodson 1994). Moreover, vertical (Copin-Montégut \& Avril 1993, Carlson et al. 1994) 


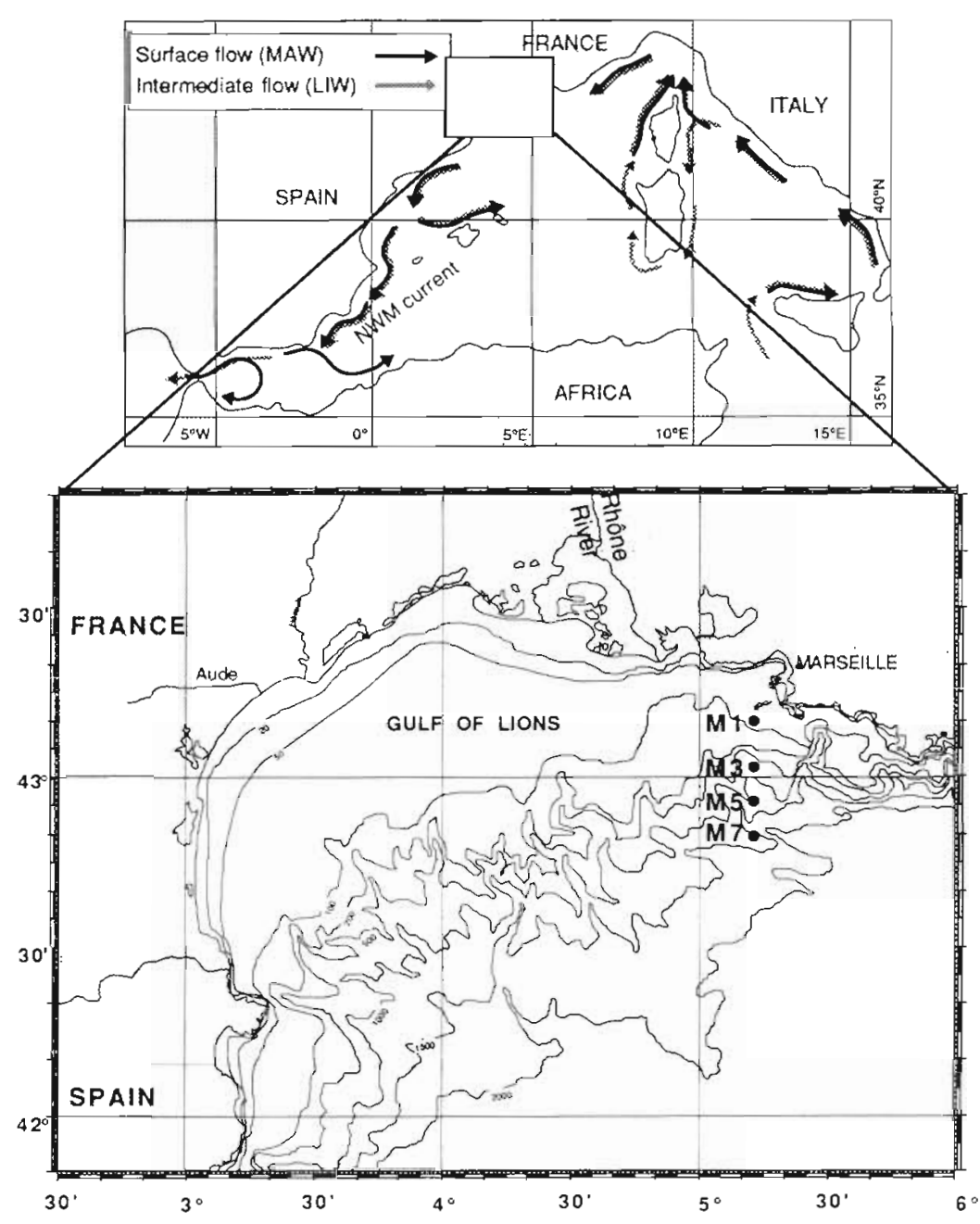

Fig. 1. Locations of the 4 stations studied (Stn M1. $43^{\circ} 10.5^{\prime} \mathrm{N}, 05^{\circ} 1.2 .5^{\prime} \mathrm{E}$; Stn M3: $43^{\circ} 02.0^{\prime} \mathrm{N}, 05^{\circ} 12.5^{\prime} \mathrm{E}_{\text {; }}$ Stn M5: $42^{\circ} 56.0^{\prime} \mathrm{N}, 0^{\circ} 12.5^{\prime} \mathrm{E}_{\text {; }} \operatorname{Stn} \mathrm{M}$ : $42^{\circ} 49.0^{\prime} \mathrm{N}, 05^{\circ} 12.5^{\prime} \mathrm{E}$ ) during the EMPS-Pauline cruise in the coastal northwestern Mediterranean Sea, 7 to 15 November 1994. Surface and intermediate circulations in the western Mediterranean Sea are indicated. Cyclonic current in the northern basin is called the northwestern Mediterranean (NWM) or Liguro-Provençal current (after Millot 1987)

and horizontal (Kepkay \& Wells 1992) advections may produce large variations in DOC concentrations and should be taken into account when DOC is included in models related to the biological pump.

Pigments and primary production measurements (Lefèvre et al. 1997 and references therein) as well as coastal zone color scanner images (Feldman 1989, Morel \& André 1991) have shown that the waters in the Gulf of Lions (northwestern Mediterranean, NWM) are oligo-mesotrophic; however, a higher mass flux and a lower percentage of photosynthetic carbon cycle through bacteria in these waters when compared to oligotrophic waters of the Aegean or southwestern Mediterranean Sea near the Baleares Islands (Bianchi et al. 1996, Turley et al. unpubl.j. Interestingly, recent works showed that in the Gulf of Lions waters bacterial growth as well as the microbial food web structure seem to be strongly related to the influence of the wind forcing, the Rhône River inputs (Soto et al. 1993), and the regional circulation (Christaki et al. 1996) i.e. the NWM or LiguroProvençal current (Fig. 1). However, to our knowledge, there is no report simultaneously dealing with crossslope variations of organic carbon, autotrophic production and bacterial activity in this area. In this paper, we discuss the vertical and horizontal distributions of DOC, particulate organic carbon (POC), bacterial abundance and chlorophyll a (chl a) concentrations related to primary and bacterial production reported by Turley et al. (unpubl.) at 4 stations in the northwestern Mediterranean Sea at 3 to 30 miles from the coast and the city of Marseille (France). We discuss the variations of these parameters in relation to hydrodynamic conditions.

\section{MATERIALS AND METHODS}

Study area. Four stations located along a cross-slope transect off Marseille were sampled during the 'EMPSPauline' cruise ( 7 to 15 November 1994) on board the RV 'Tethys II' (Fig. 1). Seawater samples were collected with 121 Niskin bottles, from the surface to $1000 \mathrm{~m}$ depth. Conductivity, temperature and depth (CTD) data were obtained in parallel to the water sampling with a Sea-Bird 19 probe. Three principal water masses are found in this area (Lacombe \& Tchernia 1972): the surface Modified Atlantic Waters (MAW), the Levantine Intermediate Water (LIW) and the Deep Western Mediterranean Water (DWMW). The MAW found in the upper $300 \mathrm{~m}$ of the water column is characterized by low salinity values between 37.90 and 38.45 . Waters with salinity values lower than 37.90 are sometimes observed at the surface and result from the dispersion of freshwater supplied by rivers (Conan 1996). The Rhone River with an annual water discharge of ca $53 \times 10^{9} \mathrm{~m}^{3} \mathrm{yr}^{-1}$ (Cauwet et al. 1990) is the main source of freshwater in the northwestern Mediterranean.

The local dynamical features are dominated by the NWM current-which flows westward on the shelf 
and along the continental slope-and the windinduced currents (Millot 1990). The NWM current, whose core essentially encompasses the MAW, is part of the general circulation in the western Mediterranean (Millot 1987). It flows cyclonically along the continental slope following a more or less steady path (Fig. 1), with a flux on the same order of magnitude as the incoming and outgoing fluxes in the Strait of Gibraltar, which are ca 1 to $2 \times 10^{6} \mathrm{~m}^{3} \mathrm{~s}^{-1}$ (Béthoux 1980, Lacombe 1988). The circulation of the LIW and DWMW is likely cyclonic and follows the isobaths. Evidence for mesoscale cross-slope displacements of the NWM current core, due to meanders, was given by Conan \& Millot (1995). X. Durrieu de Madron, $O$. Radakovitch, A. Monaco \& S. Heussner (unpubl.) further showed that these fluctuations, which have a typical period of 2 to $10 \mathrm{~d}$, are particularly intense in winter and enhance the shelf-slope exchanges of matter. The winds, which intensify in winter, also lead to highly variable and intense surface currents on the shelf. Four zones of different productivity were defined near the experimental site (Conan 1996 and references therein): (1) the Rhone River plume and its dilution zone with high nutrient concentrations; (2) a coastal eutrophic area in the Gulf of Marseille (eastern end of the Gulf of Lions; Fig. 1, near Stn M1) occasionally enriched by nutrients from the Rhône River or coastal upwelling; (3) a zone of lower productivity within the core of the NWM current on the slope (Fig. 1, between Stns M3 and M7); and (4) a productive frontal zone on the outer edge of the NWM current.

DOC and POC measurements. To avoid contamination, seawater was drained with a Teflon pipe directly from the Niskin bottle into large glass bottles (10 1) that had been cleaned with $2 \% \mathrm{HCl}$ and rinsed several times with distilled water. Seawater samples were filtered within $6 \mathrm{~h}$ in the laboratory under reduced vacuum through an all glass pre-combusted $\left(450^{\circ} \mathrm{C}\right)$ fibre filter (Whatman GF/F, $25 \mathrm{~mm}$ diameter). Filters were then frozen at $-20^{\circ} \mathrm{C}$ for $\mathrm{POC}$ analysis. The first $100 \mathrm{ml}$ of filtrate were discarded, and then $10 \mathrm{ml}$ of filtered seawater samples were transferred into pre-heated $\left(450^{\circ} \mathrm{C}\right)$ glass vials, with Teflon-lined screw caps, for DOC measurements. All samples were poisoned with $50 \mu$ of $\mathrm{HgCl}_{2}$ (final concentration: $10 \mathrm{mg} \mathrm{l}^{-1}$ ) and stored in the dark at room temperature.

For DOC analysis, we used a commercially available Shimadzu TOC 5000 system (high temperature catalytic oxidation; Sugimura \& Suzuki 1988) with a catalyst made of platinized-quartz wool. Samples were acidified $(\mathrm{pH}=2)$ with $2 \mathrm{M} \mathrm{HCl}$ and bubbled for $10 \mathrm{~min}$ with $\mathrm{CO}_{2}$-free pure air to purge inorganic carbon. Two or three $50 \mu$ replicates for each sample were injected into a column heated at $680^{\circ} \mathrm{C}$. The effluent passed through a drying unit (magnesium perchlorate car- tridge), a halogen scrubber for eliminating halogen gas and sulphates, a dust-eliminating membrane filter to remove sea-salts and phosphoric acid aerosols, and finally the non-dispersive infra-red (NDIR) cell in which $\mathrm{CO}_{2}$ was detected. The catalyst bed was preconditioned by injecting $50 \mu \mathrm{l}$ of acidified and sparged Milli-Q water until the lowest stable integrated area was obtained (between 400 and 600 area units). The analytical precision of the procedure was within $4 \%$ $(n=3)$. Of the replicate samples, $85 \%$ showed a dispersion between \pm 2 and $\pm 8 \mu \mathrm{MC}$, and the remaining $15 \%$ showed a dispersion between \pm 10 and $\pm 14 \mu \mathrm{MC}$.

Calibration curves were built with a set of standard solutions of known concentrations: $62,83,125$, and $167 \mu \mathrm{M}$ C. These solutions were prepared every day prior to analyses of seawater samples by dilution in Milli-Q water from a 'stock solution' of potassium hydrogen phthalate prepared each week. The error introduced by the standard curves was estimated to be less than $4 \%$ for the sample determination. The system blank was measured by injecting pyrolyzed and carbon free water in the combustion tube (TC blank check function of the instrument). A series of 5 replicates was made 10 times, producing at the end of the blank checking program 50 DOC measurements of the pyrolized water. The instrument blank determined by this method was $9 \mu \mathrm{MC}$. The DOC blank of Milli-Q water was found to be $6 \mu \mathrm{MC}$ and was subtracted from the DOC standard concentrations for sample DOC calculation.

In preparation for POC analysis, the GF/F filters were oven dried at $50^{\circ} \mathrm{C}$ and loaded into pre-combusted porcelain combustion boats. They were covered with a few $\mathrm{ml}$ of $2 \mathrm{~N}$ phosphoric acid and evaporated to dryness at $50^{\circ} \mathrm{C}$ for $12 \mathrm{~h}$ to remove inorganic carbon (Tan \& Strain 1979). The filters were then assayed on a CHN analyzer (CHN-800 LECO) with a combustion tube at $850^{\circ} \mathrm{C}$. The $\mathrm{CO}_{2}$ generated by oxidation was measured by a NDIR cell with a standard deviation of $2 \%$

Enumeration of bacteria. Samples were drawn from the Niskin bottles and immediately preserved in $20 \mathrm{ml}$ vials with $0.2 \mu \mathrm{m}$-filtered $2 \%$ glutaraldehyde (final concentration). Slides were prepared within $24 \mathrm{~h}$ of sampling to avoid underestimation of cell numbers due to possible losses during storage (Turley \& Hughes 1992). Samples were sonicated on ice for 30 to $120 \mathrm{~s}$ in a $50 \%$ on-off cycle using a Vibracell V $60020 \mathrm{kHz}$ ultrasonicator to ensure good distribution on the filter. An appropriate volume of sample was stained with $0.2 \mu \mathrm{m}$-filtered DAPI solution (Porter \& Feig 1980) at $1 \mu \mathrm{g} \mathrm{ml}^{-1}$ final concentration for $10 \mathrm{~min}$ before filtering onto a black $0.2 \mu \mathrm{m}$ pore-size $25 \mathrm{~mm}$ diameter Nuclepore filter (Hobbie et al. 1977). Slides were kept at $-20^{\circ} \mathrm{C}$ until counting. Standard error between replicate samples was 3 to $20 \%$ (30 fields randomly counted per sample) 


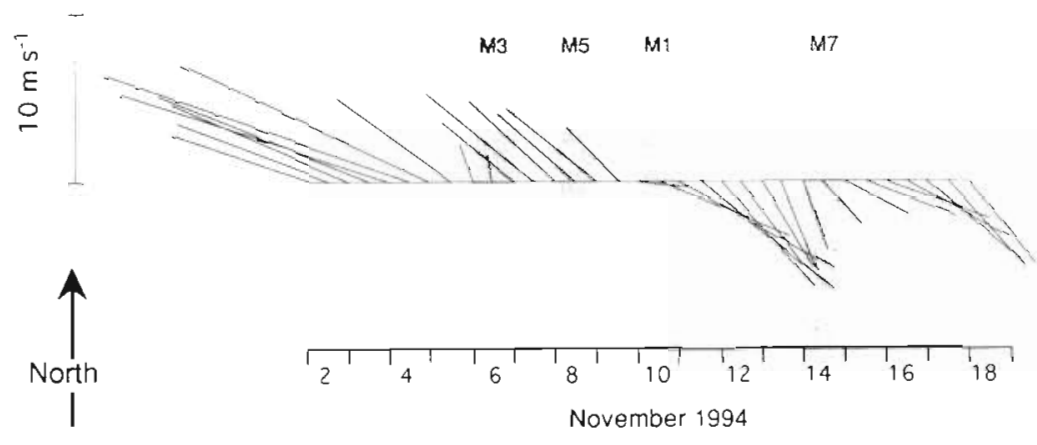

Fig. 2. Stick plot of the wind speed and direction measured near Marseilles between 2 and 18 November 1994 . Sticks are rotated by $180^{\circ}$ to indicate the leeward direction of the wind. Values are averaged over $12 \mathrm{~h}$ periods and are smoothed using 2 repeated passes of a simple hanning window. The days on which the 4 stations were sampled are shown by vertically shaded bars

prevents the surface offshore dispersion of the Rhone River plume by transporting it westward along the shore, whereas a southeastward wind induces a seaward spreading of this plume. Therefore, it appears that the low surface salinity values measured in the water column at Stn M1 (salinity between 37.90 and 37.97 ; Table 1) and particularly between 5 and $30 \mathrm{~m}$ depth at Stn M7 (salinity between 37.52 and 37.56) may be due to the influence of the Rhone River freshwater at these stations during the period sampled. The effect of the wind-induced mixing is also clearly evident at Stn M1 where all parameters (salinity, temperature, DOC, POC, bac-

$\mathrm{Chl}$ a analysis. Seawater samples were collected from the Niskin bottles in 11 opaque bottles (cleaned with $2 \%$ $\mathrm{HCl}$ and rinsed several times with distilled water) and refrigerated until their processing on land, which was always within $12 \mathrm{~h}$ after sampling. Samples were filtered onto $0.45 \mu \mathrm{m}$ pore-size Millipore HA filters ( $45 \mathrm{~mm}$ diameter). The filtration volumes ranged from 1.7 to $2.0 \mathrm{l}$. Pigments were extracted by adding $90 \%$ acetone to the homogenate which was then left overnight in the dark. Following the fluorometric determination described by Holm-Hansen et al. (1965), the measurements were performed before and after acidification with 2 drops of $1 \mathrm{~N} \mathrm{HCl}$ on a Perkin-Elmer LS-5B luminescence spectrometer. Calibration was made with pure Sigma chl a standards and a linear instrumental response over the considered range.

\section{RESULTS}

\section{Climatological and hydrological conditions}

The heavy rainfalls that occurred on the adjacent land area before and during the sampling period led to an unusually high freshwater discharge from the Rhône River (av. $5358 \mathrm{~m}^{3} \mathrm{~s}^{-1}$ for November; B. Charrière, R. Sempéré \& G. Cauwet unpubl.). Wind measured near the Rhône River mouth indicated that 2 periods of opposite wind regimes dominated during the experiment (Fig. 2) Stns M3 and M5 were sampled while the wind was northwestward, Stn M1 was sampled during the wind reversal period, and Stn M7 while the wind was southeastward. As shown by Estournel et al. (1997), a northwestward wind teria and chl a) varied only slightly down to $70 \mathrm{~m}$ deep (Table 1, Figs. 3 \& 4), indicating a relative homogenization of the shelf water column. The surface mixed layer over the slope was thickest at Stn M3 (ca 40 m).

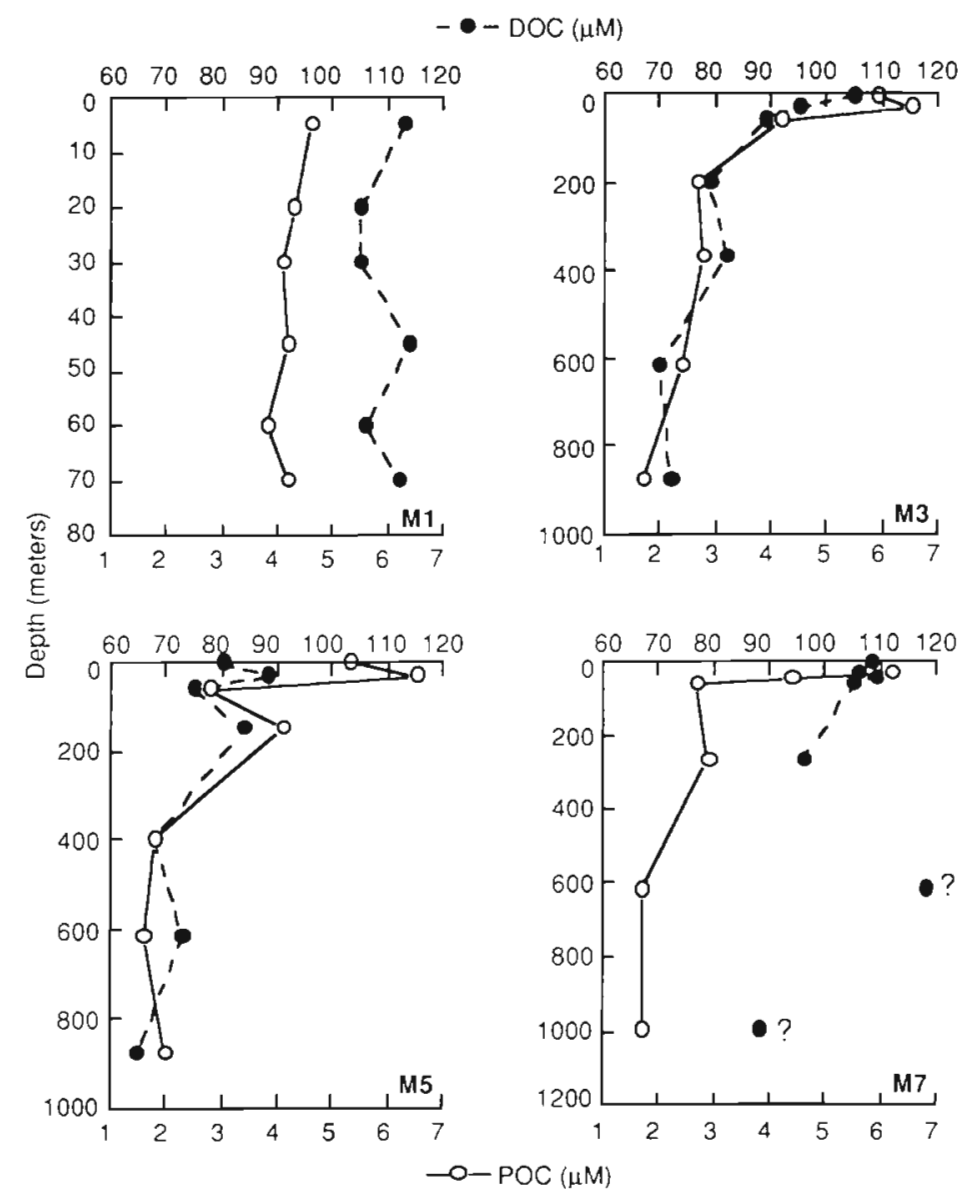

Fig. 3. Vertical distribution of DOC and POC in seawater samples collected at Stns M1, M3, M5 and M7 in the coastal northwestern Mediterranean Sea 
Table 1. Sampling dates, sample depth, DOC, POC, bacterial numbers, chl a concentrations, bacterial-C/POC (BC/POC) ratio $(\%)$, bacterial-C/phytoplankton $\mathrm{C}(\mathrm{BC} / \mathrm{Phyt}-\mathrm{C})$ ratio, salinity, and temperature from seawater samples collected from 4 stations in the northwestern Moditerranean Sea. November 1994. Ratios 1 and 2 were calculated assuming a constant C/chl a of 30 (Strickland 1960) and 100 (Fuhrman et al. 1989) in the top $70 \mathrm{~m}$, respectively. nd: not determined. POC values are not corrected for a $50 \%$ retention of bacteria on the glass fibre filters used in the filtration

\begin{tabular}{|c|c|c|c|c|c|c|c|c|c|c|}
\hline $\begin{array}{l}\text { Station and } \\
\text { sampling date }\end{array}$ & $\begin{array}{l}\text { Depth } \\
(\mathrm{m})\end{array}$ & $\begin{array}{l}\mathrm{DOC} \\
(\mu \mathrm{M})\end{array}$ & $\begin{array}{l}\text { POC } \\
(\mu \mathrm{M})\end{array}$ & $\begin{array}{c}\text { Bacteria } \\
\left(\times 10^{5} \mathrm{ml}^{-1}\right)\end{array}$ & $\begin{array}{c}\text { Chl a } \\
\left.\text { (ng }\left.\right|^{-1}\right\}\end{array}$ & $\begin{array}{c}\mathrm{BC} / \mathrm{POC} \\
(\%)\end{array}$ & $\begin{array}{c}\text { BC/Phyt-C } \\
\text { ratio } 1\end{array}$ & $\begin{array}{c}\text { BC/Phyt-C } \\
\text { ratio } 2\end{array}$ & Salinity & $\begin{array}{l}\text { Temper- } \\
\text { ature }\left({ }^{\circ} \mathrm{C}\right.\end{array}$ \\
\hline \multirow[t]{6}{*}{ M1, 10 Nov 1994} & 5 & 113 & 4.6 & 5.4 & 200 & 19 & 1.8 & 0.5 & 37.90 & 17.76 \\
\hline & 20 & 105 & 4.3 & 5.7 & 153 & 22 & 2.5 & 0.7 & 37.95 & 17.55 \\
\hline & 30 & 105 & 4.1 & 5.4 & 197 & 22 & 1.8 & 0.5 & 37.94 & 17.52 \\
\hline & 45 & 114 & 4.2 & 6.5 & 195 & 26 & 2.2 & 0.7 & 37.94 & 17.46 \\
\hline & 60 & 106 & 3.8 & 7.1 & 224 & 31 & 2.1 & 0.6 & 37.95 & 17.38 \\
\hline & 70 & 112 & 4.2 & 6.6 & 191 & 26 & 2.3 & 0.7 & 37.97 & 16.64 \\
\hline \multirow[t]{7}{*}{ M3, 6 Nov 1994} & 5 & 105 & 5.9 & 5.9 & 151 & 17 & 2.6 & 0.8 & 38.00 & 18.10 \\
\hline & 30 & 95 & 6.5 & 5.1 & 140 & 13 & 2.5 & 0.7 & 38.00 & 18.10 \\
\hline & 60 & 89 & 4.2 & 5.5 & 82 & 22 & 4.5 & 1.3 & 37.90 & 15.90 \\
\hline & 200 & 79 & 2.7 & 1.5 & 4.0 & 9 & - & - & 38.30 & 13.30 \\
\hline & 370 & 82 & 2.8 & 1.4 & 0.4 & 9 & - & - & 38.50 & 13.50 \\
\hline & 620 & 70 & 2.4 & 1.0 & 0.2 & 7 & - & - & 38.50 & 13.40 \\
\hline & 880 & 72 & 1.7 & 0.9 & 0.0 & 9 & - & - & 38.50 & 13.20 \\
\hline \multirow[t]{7}{*}{ M5, 8 Nov 1994} & 5 & 80 & 5.3 & 4.9 & 73 & 15 & 4.5 & 1.3 & 38.00 & 17.83 \\
\hline & 30 & 88 & 6.5 & 5.9 & 62 & 15 & 6.4 & 1.9 & 38.07 & 17.73 \\
\hline & 60 & 75 & 2.8 & 3.5 & 110 & 21 & 2.1 & 0.6 & 37.97 & 13.91 \\
\hline & 150 & 84 & 4.1 & 1.5 & 6.7 & 6 & - & - & 38.30 & 13.27 \\
\hline & 400 & 68 & 1.8 & 1.5 & 0.0 & 14 & - & - & 38.55 & 13.48 \\
\hline & 620 & 73 & 1.6 & 1.3 & 0.0 & 13 & - & - & 38.55 & 13.38 \\
\hline & 880 & 65 & 2.0 & 0.9 & 1.3 & 7 & - & - & 38.51 & 13.22 \\
\hline \multirow{7}{*}{ M7, 14 Nov 1994} & 5 & 108 & nd & 7.7 & 193 & nd & 2.6 & 0.8 & 37.52 & 17.49 \\
\hline & 30 & 106 & 6.2 & 6.1 & 145 & 16 & 2.8 & 0.8 & 37.56 & 17.55 \\
\hline & 45 & 109 & 4.4 & 5.3 & 131 & 20 & 2.7 & 0.8 & 38.10 & 15.24 \\
\hline & 60 & 105 & 2.7 & 4.9 & 132 & 30 & 2.5 & 0.7 & 38.07 & 14.28 \\
\hline & 270 & 96 & 2.9 & 1.9 & 1.0 & 11 & - & - & 38.53 & 13.39 \\
\hline & 620 & 118 & 1.7 & 1.1 & 0.9 & 11 & - & - & 38.52 & 13.27 \\
\hline & 1000 & 88 & 1.7 & nd & 0.6 & nd & - & - & nd & nd \\
\hline
\end{tabular}

\section{DOC, POC and TOC}

DOC concentrations in the water column ranged from 65 to $118 \mu \mathrm{M}$ (Table 1, Fig. 3) comprising 93 to $99 \%$ of the total organic carbon (TOC), with highest values rather found in the photic zone than in the underlying waters. Our DOC data for 620 and $1000 \mathrm{~m}$ depths at Stn $\mathrm{M} 7$ are doubtful, as they are significantly higher than recent measurements at the same location (50 to $60 \mu \mathrm{M}$; R. Sempéré \& L. Guilhem unpubl.). This might be due to unsteady conditions of the catalyst during measurement and/or contamination during $\mathrm{GF} / \mathrm{F}$ filtration. Integrated DOC concentrations in the surface layer $(0$ to $70 \mathrm{~m}$ ) showed that the highest stocks of DOC (Fig. 5a) were observed at stations located at the end points of the transect, i.e. coastal Stn M1 (91.2 $\mathrm{g} \mathrm{C} \mathrm{m}^{-2}$ ) and offshore Stn M7 (89.6 $\left.\mathrm{g} \mathrm{C} \mathrm{m}^{-2}\right)$. In the surface layer, DOC was positively correlated with bacteria and chl a abundances ( $p<0.01$; Fig. 6a, b) indicating that phytoplankton produced dissolved organic compounds (Lancelot 1979, Søndergaard et al. 1985, Baines \& Paice 1991) utilized by bacteria (Cole et al. 1982, Hollibaugh \& Azam 1983, Decho 1990, Amon \& Benner 1996). POC concentrations ranged from 2.7 to $6.5 \mu \mathrm{M} \mathrm{C}$ in surface waters and decreased down to $1.6 \mu \mathrm{M} \mathrm{C}$ in deeper layers (Fig. 3, Table 1). The cross-slope pattern observed for POC (Fig. 5b) in the surface layer $(0$ to $70 \mathrm{~m})$ was different from that of the DOC (Fig. 5a). POC content along the section ranged from 3.5 to $4.5 \mathrm{~g} \mathrm{C} \mathrm{m}^{-2}$, being maximum at Stn M3.

\section{Chl a and bacteria}

In the water column, bacterial cell numbers ranged from 0.9 to $7.7 \times 10^{5}$ cells ml $^{-1}$ (Fig. 4, Table 1). Bacteria in surface samples ( 0 to $70 \mathrm{~m}$ ) were slightly more abundant $\left(3.5\right.$ to $7.7 \times 10^{5}$ cells $\mathrm{ml}^{-1}$ ) on the shelf (Stn M1: $6.1 \pm 0.6 \times 10^{5}$ cells $\mathrm{ml}^{-1}$ ) and on the southmost station (Stn M7: $6.0 \pm 1.1 \times 10^{5}$ cells $\mathrm{ml}^{-1}$ ) than at M3 and M5 $\left(5.1 \pm 1.1\right.$ cells $\left.\mathrm{ml}^{-1}\right)$. However, using a tritiatedleucine incorporation technique, Turley et al. (unpubl.) indicated that bacterial production was lower near the coast (Stn M1: $65 \mathrm{mg} \mathrm{C} \mathrm{m}^{-2} \mathrm{~d}^{-1}$ ) than at other stations 


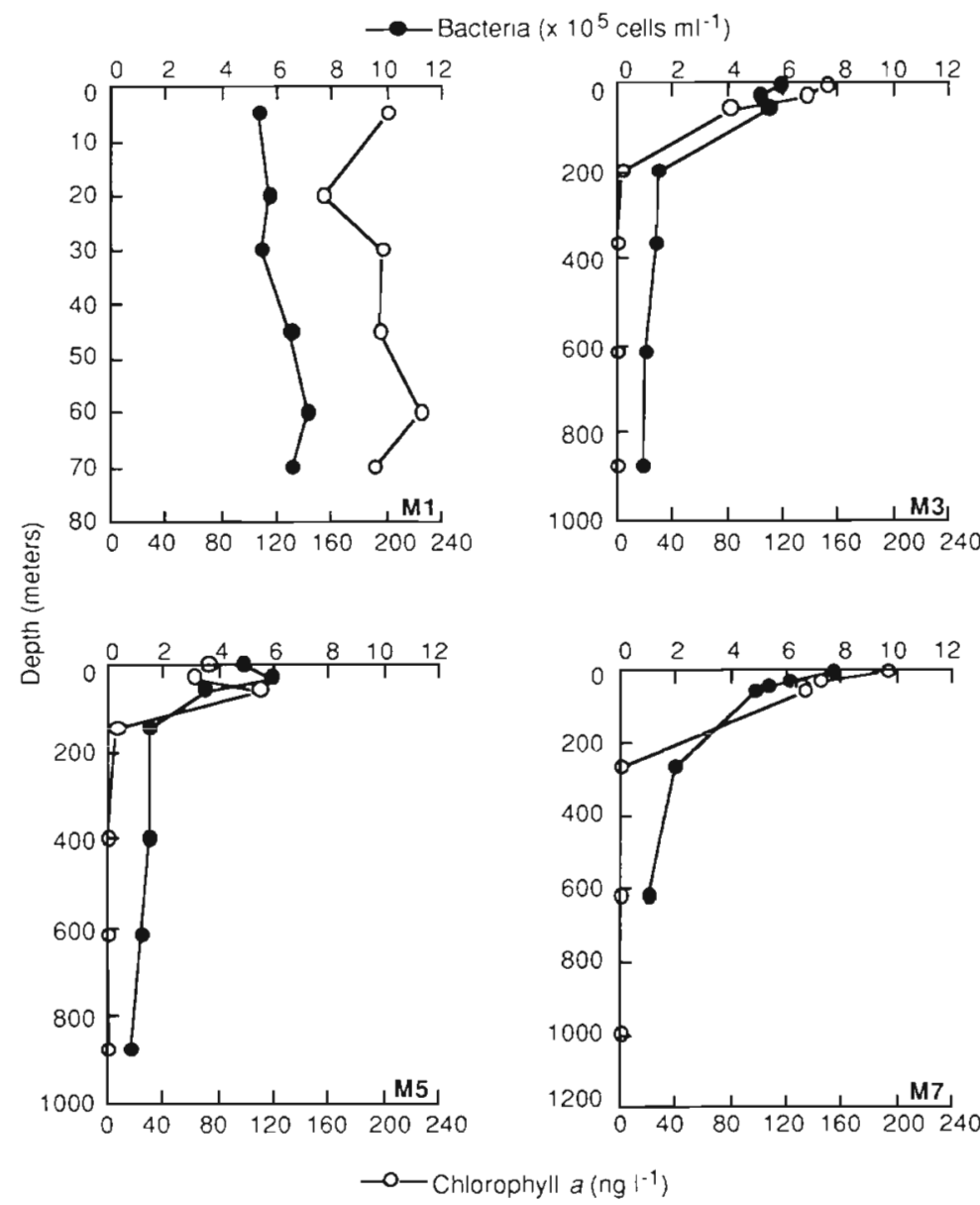

Fig. 4. Vertical distribution of bacterial numbers and chl a concentrations in seawater samples collected at Stns M1, M3, M5 and M7
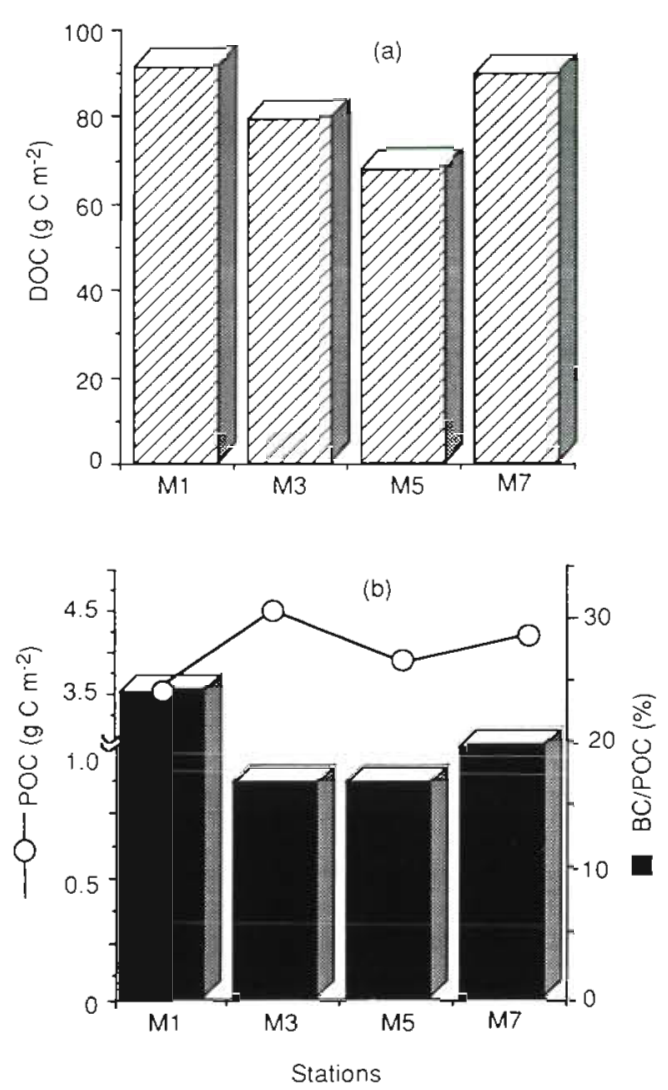

Fig. 5. Integrated concentrations (between 0 and $70 \mathrm{~m}$ depth) of (a) DOC and (b) POC and bacterial-C/POC $(\mathrm{BC} / \mathrm{POC})(\%)$ in seawater samples collected at Stns M1, M3, M5 and M7. BC calculated assuming $20 \mathrm{fg} \mathrm{C}^{\mathrm{C}}$ cell' ${ }^{-1}$ (Lee \& Fuhrman 1987) (maximum at Stn M5: $89 \mathrm{mg} \mathrm{C} \mathrm{m}^{-2} \mathrm{~d}^{-1}$ ). Assuming a conversion factor of $20 \mathrm{fg} C$ per bacterium (Lee \& Fuhrman 1987), we found that in the surface layer, the $C$ contribution of free living bacteria to suspended POC ranged from 17 to $24 \%$ (Fig. 5b). These ratios are higher at the end points of the transect (Stns M1 and M7) than at Stns M3 and M5 and are on the same order of magnitude as results reported in Atlantic Ocean (20 to $30 \%$, Ducklow et al. 1993; 25 to $33 \%$, Turley \& Mackie 1994). Integrated bacterial biomass-C in the surface layer ranged from 0.6 to $0.8 \mathrm{~g} \mathrm{C} \mathrm{m}^{-2}$.

In the surface layer, averaged chl a concentration followed the same pattern as that for bacteria, being higher at Stns M1 $\left(193 \pm 21 \mathrm{ng} \mathrm{l}^{-1}\right)$ and M7 $(150 \pm 25 \mathrm{ng}$ $\left.\mathrm{l}^{-1}\right)$ than at Stns M3 and M5 (123 \pm 30 and $81 \pm 21 \mathrm{ng} \mathrm{l}^{-1}$, respectively). By contrast, the integrated primary production measured by the ${ }^{14} \mathrm{C}$ technique was almost 3 times higher offshore (Stn M7: $367.4 \mathrm{mg} \mathrm{C} \mathrm{m}^{-2} \mathrm{~d}^{-1}$ ) than near the coast (Stn M1: $132.4 \mathrm{mg} \mathrm{C} \mathrm{m}^{-2} \mathrm{~d}^{-1}$ ). Intermediate values were found at other stations (Stns M3 and M5: $205 \pm 8 \mathrm{mg} \mathrm{C} \mathrm{m} \mathrm{C}^{-1}$ ) (Turley et al. unpubl.; Table 2) Two factors of $\mathrm{C} / \mathrm{chl}$ a conversion were used to estimate phytoplankton-C biomasses (30: Strickland 1960; 100: Fuhrman et al. 1989) in the top $70 \mathrm{~m}$. These results indicated that phytoplankton makes up 2 to $50 \%$ of POC. Moreover, these results suggested that bacterial-C/phytoplankton-C ratios ranged from 0.5 to 6.4 , being higher at Stns M3 and M5 than at Stns M7 and M1 (Table 1)

\section{DISCUSSION}

\section{DOC, bacteria and chl a distribution}

DOC concentrations measured at Stns M1, M3 and M7 were very close to those already reported in the Rhône River plume (Cauwet et al. 1990, Cauwet \& Oriol 1994). By contrast, the lower values observed at Stn M5 were rather similar to those reported for the oligotrophic offshore DYFAMED station (Copin-Montégut \& Avril 1993). Bacterial cell numbers as well as 


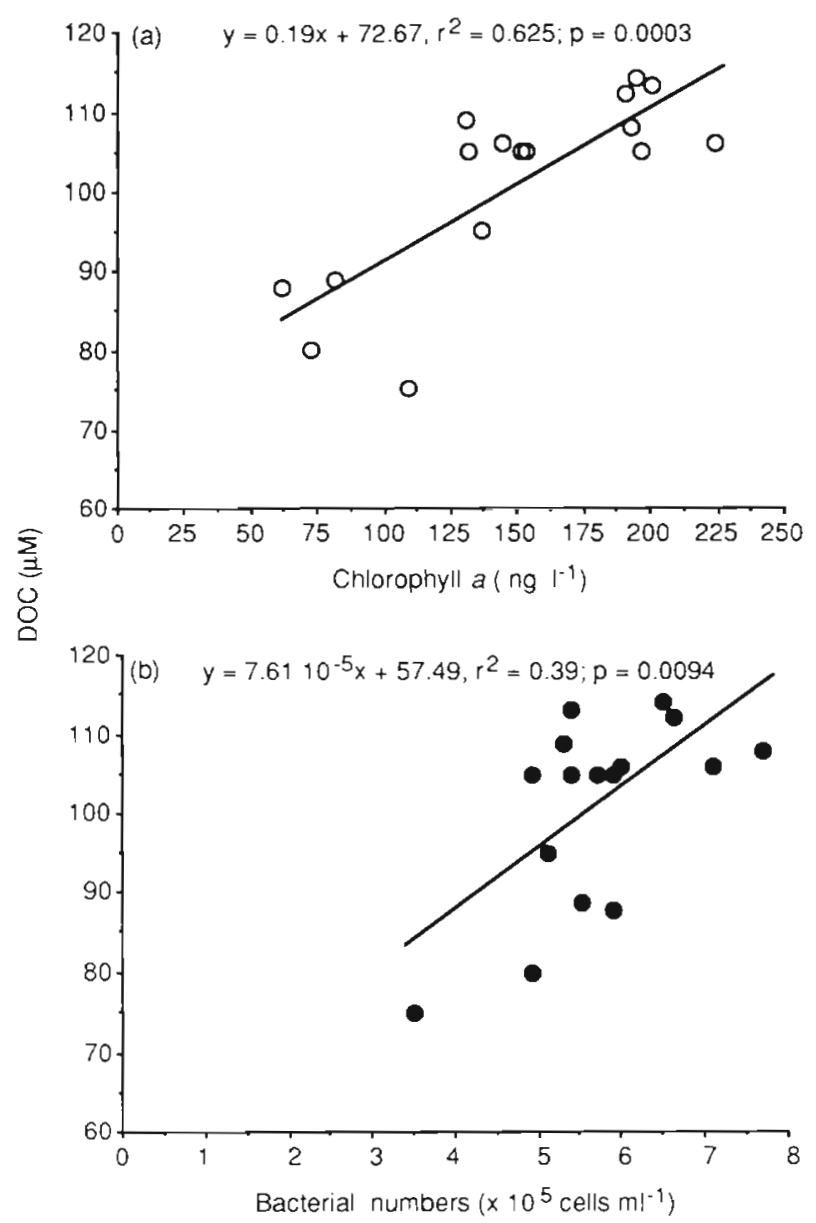

Fig. 6. Regressions between 0 and $70 \mathrm{~m}$ depth of (a) DOC vs chl $a$ and (b) DOC vs bacterial densities in seawater samples collected at Stns M1, M3, M5 and M7

chl a measured here are in the same range as those previously reported in the Mediterranean Sea (Kirchman et al. 1989, Zohary \& Robarts 1992, Soto et al. 1993, Bianchi \& Giuliano 1996). However, it should be noticed that the spatial distributions of integrated

Table 2. Estimates of integrated primary production (PP) and integrated baclenal production (BP) from the sea surface to the base of the deep chlorophyll maximum (DCM: $60 \mathrm{~m}$ depth) in the northwestern Mediterranean Sea (data summarized from Turley et al. unpubl.). Bacterial carbon demand $(B C D)$ is calculated assuming a $40 \%$ bacterlal growth efficiency (Bjornsen \& Kuparinen 1991)

\begin{tabular}{|lcccc|}
\hline & Stn M1 & Stn M3 & Stn M5 & Stn M7 \\
\hline BP $\left(\mathrm{mg} \mathrm{C} \mathrm{m}^{-2} \mathrm{~d}^{-1}\right)$ & 64.9 & 74.2 & 89.3 & 75.5 \\
PP $\left(\mathrm{mg} \mathrm{C} \mathrm{m}^{-2} \mathrm{~d}^{-1}\right)$ & 132.4 & 212.4 & 197.3 & 367.4 \\
BP/PP (\%) & 49 & 35 & 45 & 20 \\
BCD/PP (\%) & 123 & 88 & 113 & 50 \\
\hline
\end{tabular}

DOC, bacteria and chl a biomass-C did not vary conservatively with distance from the coast. Moreover, the low surface salinity data measured at Stns M7 (37.52) and M1 (37.90) may be due to inputs of freshwater from the Rhône River in the whole water column and for the 5 to $30 \mathrm{~m}$ layer respectively during the period sampled. Indeed, the southeastward direction of the wind was reported to induce a seaward spreading of the plume (Estournel et al. 1997). Moreover, this spreading was enhanced by the strong rains which occurred during November 1994, yielding an unusually high Rhône water discharge. However, since integrated primary production offshore (Stn M7) was 2 or 3 times higher than near the coast (Stn M1) or the slope (Stns M3 and M5), it is likely that primary production contributed more to the DOC production offshore than at other stations during the period sampled.

Interestingly, integrated bacterial production comprized $20 \%$ offshore (Stn M7) and $49 \%$ near the coast (Stn M1) of the integrated primary production. Assuming a growth efficiency of $40 \%$ (Bjørnsen \& Kuparinen 1991 ), then 50 and $123 \%$ of primary production may be routed through the DOC reservoir and support the bacterial carbon demand (BCD) at Stns $M 7$ and M1 respectively. This suggests that, during the sampling period, a greater proportion of primary production flowed to the microbial food web near the coast than offshore and/or that additional sources of DOC such as Rhône River organic compounds substantially sustained bacterial production at Stn M1. Such figures are probably underestimates since recent work suggested that the bacterial growth efficiency might range from less than 10 to $25 \%$ (del Giorgio et al. 1997). Similar calculations for Stns M3 and M5 indicate integrated bacterial production to comprise 35 and $45 \%$ respectively of the integrated primary production. As a consequence, 88 and $113 \%$ of primary production should be required to support the BCD, which is much higher than that reported at Stn M7. Since the area including Stns M3 and M5 is very likely under the influence of the NWM current (Conan 1996) with a small influence from the Rhône River, these results suggest a difference in the food web structure between the slope (Stns M3 and M5) and offshore (Stn M7).

Bacterial-C/phytoplankton-C ratio was found to be maximum at Stn M1 which is probably due to the organic carbon input from the Rhône River as suggested above. Interestingly, this ratio is higher at Stns M3 and, particularly, M5 than at Stn M7, being in good agreement with bacterial production/primary production ratios. This suggests that, during the sampling period, heterotrophic bacterial biomass was relatively more important on the slope than offshore when compared to phytoplanktonic biomass. More generally, it seems that the predominance of heterotrophic 
biomass over autotrophic biomass is typical of oligotrophic systems (Fuhrman et al. 1989, Cho \& Azam 1990. Booth et al. 1993), with an exception reported for the eastern Mediterranean (Robarts et al. 1996). This seems to be consistent with physical measurements $(T, S)$ indicating that during the period sampled, Stn M3 and, more likely, M5 are characteristic of the oligotrophic NWM current, being in agreement with the study of Conan (1996)

Higher bacterial production when compared to primary production as well as the lower DOC value at Stn M5 supports the study of Christaki et al. (1996), which concluded that the oligotrophic NWM current induced a predominance of the heterotrophic biomass over the autotrophic biomass at Stn M3. One explanation for this heterotrophic predominance may be a time lag between peaks of primary production and heterotrophic utilization of the labile DOC (Ducklow et al. 1993, del Giorgio et di. 1997). This explanation might be consistent with the lower DOC values observed at Stns M3 and M5 than at Stn M7. Another possibility may be a higher zooplankton activity at Stns M3 and M5 than at Stn M7. High zooplankton activity may favour the bacterial activity by excretion, sloppy feeding as well as by removal of bacterivores (Peduzzi \& Herndl 1992, Christaki et al. 1996, Van Wambeke et al 1996). In addition to the spatial variability, temporal variability cannot be precluded in this area as was previously shown for the Stn M3 (Christaki et al. 1996).

Considering an $82 \mu \mathrm{M}$ DOC concentration in the surface layer ( 0 to $300 \mathrm{~m}$ ) at M5 as typical of the NWM current in this area, and a NWM water flux of 1 to $2 \times$ $10^{6} \mathrm{~m}^{3} \mathrm{~s}^{-1}$ (Béthoux 1980, Lacombe 1988), we estimated the DOC flux of the NWM current for November 1994 to range from 82 to $164 \times 10^{3} \mathrm{~mol} \mathrm{C} \mathrm{s}^{-1}$. Such a DOC flux is ca 100 times higher than that generated by the Rhône River (Cauwet et al. 1990, Charrière et al. unpubl.) and shows that the NWM current plays a significant role on the organic carbon distribution in the Gulf of Lions.

\section{Conclusion}

Investigations at 4 stations located offshore from Marseille in the western Mediterranean showed crossslope variations in organic carbon, bacterial and chl a biomass as well as bacterial and primary production. Wind data measured during the cruise and surface salinity values observed suggest that Stns M3 and M5 located on the slope were likely representative of the oligotrophic NWM current. During the period sampled, the offshore Stn M7 was located on the outer edge of the current. However, the Rhone River influence was also suggested on the shelf (Stn M1) as well as offshore (Stn M7). We observed higher concentrations of DOC at these 2 opposite stations than on the slope (particularly at Stn M5). Although average chl a was higher on the shelf than on the slope, integrated primary production was maximum offshore and minimum on the shelf. At this station, the proportion of primary production required to support the bacterial production was higher (123\%) than at other stations where the BCD was 50 to $113 \%$ of the primary production. This over-utilization could be fuelled by inputs of terrestrial DOC carried by the Rhône River onto the shelf. Differences between the $\mathrm{BCD}$ offshore $(50 \%)$ and within the NWM current $(113 \%, \operatorname{Stn}$ M5) may be due to a time lag between peaks of primary and bacterial production during the period sampled and/or higher zooplanktonic activity on the slope which can enhance bacterial activity by grazing and sloppy feeding as well as by bacterivorous predation. Such difference in the food web structure might be explained by hydrological and chemical conditions ( $T, S$, nutrients) generated by the intensity of the Rhône River influence and the NWM current. Further works should examine temporal variations of organic carbon and bacteria in such a dynamic area.

Acknowledgements. We are grateful to Drs Armand Bianchi, Pascal Conan, Serge Heussner and France Van Wambeke for helpful discussions and comments on the manuscript as well as to Dr Gaby Gorsky and Marc Picheral for providing temperature and salinity data set. We also thank Dr Nicole Garcia for POC measurements and the captain and crew of RV 'Tethys II' for excellent service at sea. This research has been undertaken in the framework of the Mediterranean Target Project (MTP)-EMPS project. We acknowledge the support from the European Commission's Marine Science and Technology (MAST) Programme under contract MAS2-CT940090 .

\section{LITERATURE CITED}

Amon RMW. Benner R (1996) Bacterial utilization of different size classes of dissolved organic matter Limnol Oceanogr 4:41-51

Baines S, Pace M (1991) The production of dissolved organic matter by phytoplankton and its importance to bacteria: pattern across marme and freshwater systems. Limnol Oceanogr 36:1078-1090

Béthoux JP (1980) Mean water fluxes across sections in the Mediterranean Sea, evaluated on the basis of water and salt budgets and of observed salinities. Oceanol Acta 3: $79-88$

Bianchi A, Giuliano L (1996) Enumeration of viable bacteria in the marine pelagic environment. Appl Environ Microbiol 62:174-177

Bianchi M, Turley CM, Van Wambeke F, Stutt E, Christaki U, Psara S. Conan P (1996) A first and preliminary description of a relationships between the cycling of the primary production by bacteria in the photic zone and the extent of particles flux measured during the MTP pilot phase. Mediterranean Target. Project News, p 8-9 
Bjornsen PK, Kuparinen J (1991) Determination of bacterioplankton biomass, net production and growth efficiency in the Southern Ocean. Mar Ecol Prog Ser 71:185-194

Booth BC, Lewin J, Postel JR (1993) Temporal variation in the structure of autotrophic and heterotrophic communities in the subarctic Pacific. Prog Oceanogr 32:57-99

Carlson CA, Ducklow HW, Michaels AF (1994) Annual flux of dissolved organic carbon from the euphotic zone in the northwestern Sargasso Sea. Nature 371:405-408

Cauwet G, Gadel F, De Souza Sierra MM, Donard O, Ewald $M(1990)$ Contribution of the Rhône River to organic inputs to the northwestern Mediterranean Sea. Cont Shelf Res 10:1025-1037

Cauwet G, Oriol L. (1994) Dissolved organic nitrogen and carbon in the Rhône River plume. In: Martin JM, Barth H (eds) Water pollution research report 32, EROS 2000, Fifth Workshop on the north-west Mediterranean Sea, Hamburg (Germany), 28-30 March 1994, p 61-68

Cho BC, Azam F (1990) Biogeochemical significance of bacterial biomass in the ocean's euphotic zone. Mar Ecol Prog Ser 63:253-259

Christaki U, Van Wambeke F, Christou ED, Conan P, Gaudy R (1996) Food web structure variability in the surface layer, at a fixed station influenced by the northwestern Mediterranean Current. Hydrobiologia 321:145-153

Coffin RB, Connoly JP, Harris PS (1993) Availability of dissolved organic carbon to bacterioplankton examined by oxygen utilization Mar Ecol Prog Ser 101:9-22

Cole JJ, Likens GE, Straver DL (1982) Photosynthetically produced dissolved organic carbon: an important carbon source for planktonic bacteria. Limnol Oceanogr 27:1080-1090

Conan P (1996) Variabilité et bilan de la production primaire en zone côtière (Méditerranée Nord occidentale; entrée du Golfe du Lions) en relation avec les systèmes biologique, chimique et hydrodynamique (courant Nord Méditerranéen). PhD thesis, Aix-Marseille II University

Conan P. Millot C (1995) Variability of the northern current off Marseille, western Mediterranean Sea, from February to June 1992. Oceanol Acta 18:193-205

Copin-Montégut G, Avril B (1993) Vertical distribution and temporal variation of dissolved organic carbon in the northwestern Mediterranean Sea. Deep Sea Res 40: $1963-1972$

Decho AW (1990) Microbial response secretions in ocean environments: their role in food webs and marine processes. Oceanogr Mar Biol Annu Rev 28:73-154

del Giorgio P, Cole JJ, Cimbleris A (1997) Respiration rates in bacteria exceeds phytoplankton production in unproductive aquatic systems. Nature 385:148-151

Ducklow HW, Kirchman DL, Quinby HL, Carlson CA, Dam HG (1993) Stocks and dynamics of bacterioplankton during the spring bloom in the eastern North Atlantic Ocean. Deep Sea Res 40:245-263

Estournel C, Kondrachoff V, Marsaleix P, Vehil R (1997) The plume of the Rhone: numerical simulation and remote sensing. Cont Shelf Res 17:899-924

Feldman G (1989) CZCS images. NSF/NASA. US Global Flux Study Office, Woods Hole

Fuhrman JA, Sleeter TD, Carlson CA, Proctor LM (1989) Dominance of bacterial biomass in the Sargasso Sea and its ecological implications. Mar Ecol Prog Ser 57:207-217

Hobbie JE, Daley RJ, Jasper S (1977) Use of Nuclepore filters for counting bacteria by fluorescence microscopy. Appl Environ Microbiol 33:1225-1228

Hollibaugh JT, Azam F (1983) Microbial degradation of dissolved proteins in seawater. Limnol Oceanogr 28: $1104-1116$
Holm-Hansen O, Lorenzen CJ, Holmes RW Strickland JDH (1965) Fluorometric determination of chlorophyll. J Cons Perm Int Explor Mer 30:3-15

Jumars PA, Penry DL, Baross JA, Perry MJ, Frost B (1989) Closing the microbial loop: dissolved organic pathway to heterotrophic bacteria from incomplete ingestion, digestion and absorption in animals. Deep Sea Res 36 : $483-495$

Kepkay PE, Wells ML (1992) Dissolved organic carbon in North Atlantic surface waters. Mar Ecol Prog Ser 80: $275-283$

Kirchman DL, Soto-Mercado Y, Van Wambeke F, Bianchi M (1989) Bacterial production in the Rhone River plume: effect of mixing on relationships among microbial assemblages. Mar Ecol Prog Ser 53:267-275

Lacombe $\mathrm{H}$ (1988) Considerations generales sur l'océanographie physique méditérraneenne. In: Minas HJ, Nival P (eds) Pelagic Mediterranean oceanography. Oceanol Acta, NSP 9:7-12

Lancelot C (1979) Gross excretion rates of natural marine phytoplankton and heterotrophic uptake of excreted products in the southern North Sea, as determined by short-term kinetics. Mar Ecol Prog Ser 1:179-186

Lee S, Fuhrman JA (1987) Relationships between biovolume and biomass of naturally derived marine bacterioplankton. Appl Environ Microbiol 53:1298-1303

Lefevre D, Minas HJ, Minas M, Robinson C, Leb WPJ (1997) Review of gross community production, primary production, net community production and dark respiration in the Gulf of Lions. Deep Sea Res II 44:801-832.

Mantoura RFC, Woodward EMS (1983) Conservative behaviour of riverine dissolved organic carbon in the Severn Estuary: chemical and geochemical implicatıons. Geochim Cosmochum Acta 47:1293-1309

Millot C (1987) Circulation in the western Mediterranean Sea Oceanol Acta 10:143-149

Millot C (1990) The Gulf of Lions's hydrodynamics. Cont Shelf Res 10:885-894

Moran MA, Hodson RE (1994) Support of bacterioplankton production by dissolved humic susbtances from three marine environments. Mar Ecol Prog Ser 1 10:241-247

Morel A, André J (1991) Pigment distribution and primary production in the western Mediterranean as derived and modelled from Coastal Zone Colour Scanner observations. J Geophys Res 96:12685-12698

Peduzzi P, Herndl G (1992) Zooplankton activity fueling the mucrobial loop: differential growth response of bacterial from oligotrophic and eutrophic waters. Limnol Oceanogr 37:1087-1092

Porter KG, Feig YS (1980) The use of DAPl for identifying and counting aquatic microflora. Limnol Oceanogr 25:943-948

Repeta DJ, Timothy TE, Chen RF, Alhuware L (1995) Export and molecular-level characterisation of dissolved organic matter from the north-eastern US continental shelf. In: Grimalt JO, Dorronsoro C (eds) Organic geochemistry: developments and application to energy, climate, environment and human history. University of the Basque Country, Donostia-San Sebastiàn, p 1156-1157

Richey JE, Brock JT, Naiman RJ, Wissmar RC, Stallard RF (1980) Organic carbon: oxidation and transport in the Amazon river. Science 207:1348-1351

Robarts RD, Zohary T, Waiser MJ, Yacobi YZ (1996) Bacterial abundance, biomass, and production in relation to phytoplankton biomass in the Levantine Basin of the southeastern Mediterranean Sea. Mar Ecol Prog Ser 137:273-281

Romankevich EA (1984) Geochemistry of organic matter in the ocean. Springer-Verlag, Berlin 
Sempéré R, Cauwet G, Randon. J (1994) Ultrafiltration of seawater with a zirconium and aluminium oxide tubular membrane: application to the study of colloidal organic carbon distribution in an estuanne bottom nepheloid layer. Mar Chem 46:49-60

Søndergaard M, Riemann B, Jorgensen NOG (1985) Extracellular organic carbon (EOC) released by phytoplankton and bacterial production. Oikos 45:323-332

Soto Y, Bianchi M, Martinez J, Vives-Rego J (1993) Seasonal evolution of microplanktonic communities in the estuarine front ecosystem of the Rhône River plume (northwestern Mediterranean Sea). Estuar Coast Shelf Sci 37:1-13

Strickland JDH (1960) Measuring the production of marine phytoplankton. Bull Fish Res Bd Can 122:1-172

Sugimura Y, Suzuki Y (1988) A high-temperature catalytic oxidation method for determination of non-dissolved organic carbon in sea water by indirect injection of a liquid sample. Mar Chem 24:105-131

Tan FC, Strain PM (1979) Carbon isotope ratios of particulate

Editorial responsibility: Otto Kinne (Editor),

Oidendouf/Luhe, Germany organic matter in the Gulf of St. Lawrence. J Fish Res Bd Can 36:678-682

Turley CM. Hughes DJ (1992) Effects of storage on direct estimates of bacterial numbers of preserved seawater samples. Deep Sea Res 39:375-394

Turley CM, Mackie PJ (1994) Biogeochemical significance of attached and free-living bacteria and the flux of particles in the NE Atlantic Ocean. Mar Ecol Prog Ser 115:191-203

Van Wambeke F. Christaki U, Gaudy R (1996) Carbon fluxes from the microbial food web to mesozooplankton. An approach in the surface layer of a pelagic area (NW Mediterranean Sea). Oceanol Acta 19:57-66

Wangersky PJ (1978) Production of dissolved organic matter. In: Kinne $O$ (ed) Marine ecology. J Wiley, New York, p $115-220$

Zohary T, Robarts RD (1992) Bacterial numbers, bacterial production, and heterotrophic nanoplankton abundance in a warm core eddy in the eastern Mediterranean. Mar Ecol Prog Ser 84:133-137

Submitted: May 20, 1997; Accepted: November 5, 1997

Proofs reccived from author(s): December 23, 1997 